\section{Sequential Controlled Atmosphere Storage for 'McIntosh' Apples}

\author{
P. Guy Lévesque ${ }^{1}$ \\ Department of Plant Agriculture, University of Guelph, Ontario, N1G 2W1, \\ Canada
}

\author{
Jennifer R. DeEll \\ Ontario Ministry of Agriculture and Food, 1283 Blueline Rd. and Highway 3, \\ Simcoe, Ontario, N3Y 4N5, Canada

Dennis P. Murr
Department of Plant Agriculture, University of Guelph, Ontario, N1G 2W1,
Canada

Additional index words. Malus domestica, low oxygen injury, firmness retention, oxygen stress, physiological disorders, ultralow oxygen

Abstract. Sequential decreases or increases in the levels of $\mathrm{O}_{2}$ in controlled atmosphere (CA) were investigated as techniques to improve fruit quality of 'McIntosh' apples (Malus Xsylvestris [L.] Mill. var. domestica [Borkh.] Mansf.), a cultivar that tends to soften rapidly in storage. Precooled fruit that were harvested at optimum maturity for long-term storage were placed immediately in different programmed $\mathrm{CA}$ regimes. In the first year, CA programs consisted of 1) 'standard' CA (SCA; 2.5-3.0\% $\mathrm{O}_{2}+\mathbf{2 . 5 \%} \mathrm{CO}_{2}$ for the first $30 \mathrm{~d}, 4.5 \% \mathrm{CO}_{2}$ thereafter) at $3{ }^{\circ} \mathrm{C}$ for $\left.180 \mathrm{~d} ; 2\right)$ low $\mathrm{CO}_{2} \mathrm{SCA}\left(2.5-3.0 \% \mathrm{O}_{2}+\right.$ $\left.2.5 \% \mathrm{CO}_{2}\right)$ at $3{ }^{\circ} \mathrm{C}$ for $60 \mathrm{~d}$, transferred to low $\mathrm{O}_{2}\left(\mathrm{LO} ; 1.5 \% \mathrm{O}_{2}+1.5 \% \mathrm{CO}_{2}\right)$ at 0 or $3{ }^{\circ} \mathrm{C}$ for $60 \mathrm{~d}$, and then to ultralow $\mathrm{O}_{2}\left(\mathrm{ULO} ; 0.7 \% \mathrm{O}_{2}+1.0 \% \mathrm{CO}_{2}\right)$ at 0 or $3{ }^{\circ} \mathrm{C}$ for $60 \mathrm{~d}$; and 3 ) ULO at $3{ }^{\circ} \mathrm{C}$ for $60 \mathrm{~d}$, transferred to $\mathrm{LO}$ at 0 or $3{ }^{\circ} \mathrm{C}$ for $60 \mathrm{~d}$, and then to SCA or low $\mathrm{CO}_{2} \mathrm{SCA}$ at 0 or $3{ }^{\circ} \mathrm{C}$ for $60 \mathrm{~d}$. In the second year, the regimes sequentially decreasing in $\mathrm{O}_{2}$ were compared with continuous ULO and SCA. After removal from storage, apples were held in ambient air at $20{ }^{\circ} \mathrm{C}$ for a 1-week ripening period. Fruit firmness was evaluated after 1 and $7 \mathrm{~d}$ at $20{ }^{\circ} \mathrm{C}$, whereas the incidence of physiological disorders was assessed only after $7 \mathrm{~d}$. Lowering the temperature while decreasing $\mathrm{O}_{2}$ was the best CA program with significant increased firmness retention during storage and after the 1-week ripening period. Reduced incidence of low $\mathrm{O}_{2}$ injury in decreasing $\mathrm{O}_{2}$ programs and absence of core browning at the lower temperature were also observed.

In comparison with conventional cold storage, controlled atmosphere (CA) storage offers the advantage of preserving pome fruit quality for an extended period of time (Kader, 1992). Apples kept in CA in which $\mathrm{O}_{2}$ levels are below $2.5 \%$ are generally firmer (Blanpied et al., 1987; Lau, 1983, 1985, 1990) and have lower incidences of superficial scald and core flush (Blanpied et al., 1987; Chen et al., 1985; Truter and Combrink, 1994; Wang and Dilley, 1999). The level of sensitivity to low $\mathrm{O}_{2}$ atmospheres varies with apple cultivar. As a consequence of the accumulation of products of fermentation some low $\mathrm{O}_{2}$, sensitive fruit like 'McIntosh' (Autio et al., 1990; Lau et al., 1987) may develop low $\mathrm{O}_{2}$ injury (Nichols and Patterson, 1987). (Lidster and McRae 1985) and (Lidster et al. 1987) demonstrated that the use of sequential periods in $1 \%$ to $3 \% \mathrm{O}_{2}$ instead of continuous $3 \% \mathrm{O}_{2}$ resulted in higher firmness retention

Received for publication 11 Jan. 2006. Accepted for publication 10 Apr. 2006. For their technical support, we thank Len Wiley at the University of Guelph and the lab of Clément Vigneault at the Horticultural Research and Development Center. ${ }^{1}$ To whom the reprint requests should be addressed. e-mailglevesqu@wsu.edu. and reduced core browning in 'McIntosh' apples. Additionally, fruit stored in sequential regimens showed decreased incidence of flesh browning and low $\mathrm{O}_{2}$ injury when compared with fruit stored in continuous low $\mathrm{O}_{2}$.

In addition to being sensitive to low $\mathrm{O}_{2}$, 'McIntosh' is also chilling-sensitive (Lau et al., 1987; Marmo et al., 1985) and is normally stored in CA at $3{ }^{\circ} \mathrm{C}$ to prevent the development of core browning and stem cavity browning (DeEll and Murr, 2003). (Little and Peggie 1987) reported that acclimation to low temperature reduced the incidence of flesh browning and core browning in 'Jonathan' and 'Granny Smith' apples. However, the reduction of disorders in conwas accompanied by an increase in flesh softening and skin yellowing, which was not the case when fruit were stored constantly in low $\mathrm{O}_{2}\left(1.5 \% \mathrm{O}_{2}+1 \% \mathrm{CO}_{2}\right)$.

For this study, it was hypothesized that acclimatization to low $\mathrm{O}_{2}$ and low temperature could improve the long-term storage potential of 'McIntosh' apples compared with the CA regime currently used. Sequential reductions in $\mathrm{O}_{2}$ with and without a temperature reduction from 3 to $0{ }^{\circ} \mathrm{C}$ during the storage period were examined. ventional $\mathrm{CA}\left(2-5 \% \mathrm{O}_{2}+2 \%\right.$ to $\left.5 \% \mathrm{CO}_{2}\right)$
Plant material

In year 1, 'McIntosh' apples were harvested at optimum maturity for long-term storage (Cornell starch index $[\mathrm{CSI}]=3.5$, internal ethylene concentration [IEC] = $0.02 \mu \mathrm{L} / \mathrm{L}^{-1}$ ) on 11 Sept. 2000, from a commercial grower in Franklin, Quebec. Fruit were precooled $12 \mathrm{~h}$ overnight at $0{ }^{\circ} \mathrm{C}$ and separated into 2 replicates at the Horticultural Research and Development Center (HRDC), Agriculture and Agri-Food Canada, St.-Jeansur-Richelieu, Quebec. Before placement into the experimental CA chambers, the apples were separated into mesh onion bags containing 30 apples each. Each of the CA chambers held 120 fruit $(2$ reps $\times 2$ bags $\times$ 30 fruit), and all CA chambers were located in large refrigerated rooms.

In year 2, 'McIntosh' apples were harvested on 31 Aug., 2001 (CSI = 2, IEC = $0 \mu \mathrm{L} / \mathrm{L}^{-1}$ ) from a commercial grower in St. Grégoire, Quebec. Immediately after harvest, fruit was transported to the Postharvest Laboratory at the University of Guelph in recyclable plastic boxes where they were precooled $12 \mathrm{~h}$ overnight at $0{ }^{\circ} \mathrm{C}$. Each $\mathrm{CA}$ regime had 3 replicates, with each replicate being one box of approximately 120 fruit each. CA chambers holding the boxes were located within large refrigerated rooms.

\section{Controlled atmosphere treatments}

In year 1, the CA programs (Fig. 1) were separated into 3 main categories: control, stepwise decreased $\mathrm{O}_{2}$ and $\mathrm{CO}_{2}$ concentrations, and stepwise increased $\mathrm{O}_{2}$ and $\mathrm{CO}_{2}$ concentrations. A subroutine within the latter two categories in which temperature was increased or decreased after the first or second $60-\mathrm{d}$ storage period was also incorporated. CA programs consisted of 1) "standard" CA (SCA; 2.5\%-3.0\% $\mathrm{O}_{2}+2.5 \% \mathrm{CO}_{2}$ for the first $30 \mathrm{~d}, 4.5 \% \mathrm{CO}_{2}$ thereafter) at $3{ }^{\circ} \mathrm{C}$ for $180 \mathrm{~d}$; 2) low $\mathrm{CO}_{2} \mathrm{SCA}\left(2.5-3.0 \% \mathrm{O}_{2}+\right.$ $2.5 \% \mathrm{CO}_{2}$ ) at $3{ }^{\circ} \mathrm{C}$ for $60 \mathrm{~d}$, transferred to low $\mathrm{O}_{2}\left(\mathrm{LO} ; 1.5 \% \mathrm{O}_{2}+1.5 \% \mathrm{CO}_{2}\right.$ ) at 0 or $3{ }^{\circ} \mathrm{C}$ for $60 \mathrm{~d}$, and then to ultralow $\mathrm{O}_{2}$ (ULO; $0.7 \% \mathrm{O}_{2}$ $+1.0 \% \mathrm{CO}_{2}$ ) at 0 or $3{ }^{\circ} \mathrm{C}$ for $60 \mathrm{~d}$; and 3 ) ULO at $3{ }^{\circ} \mathrm{C}$ for $60 \mathrm{~d}$, transferred to $\mathrm{LO}$ at 0 or $3{ }^{\circ} \mathrm{C}$ for $60 \mathrm{~d}$, and then to SCA or low $\mathrm{CO}_{2} \mathrm{SCA}$ at 0 or $3{ }^{\circ} \mathrm{C}$ for $60 \mathrm{~d}$ at either $2.5 \%$ or $4.5 \% \mathrm{CO}_{2}$. The chambers were physically moved to a refrigerated room at $0{ }^{\circ} \mathrm{C}$ when a reduction in temperature was required.

In year 2, only the stepwise decrease in $\mathrm{O}_{2}$ and $\mathrm{CO}_{2}$ concentrations described previously was repeated (Fig. 2), because fruit quality after storage under the stepwise increase in $\mathrm{O}_{2}$ and $\mathrm{CO}_{2}$ concentrations atmosphere was poor in year 1 . The interval time was $58 \mathrm{~d}$ and the total storage time was $174 \mathrm{~d}$. These treatments were compared with fruit stored continuously in SCA and ULO.

\section{Firmness assessment}

After the indicated storage period, fruit was removed from storage and assessed for firmness on day 1 and day 7 during a ripening period of 1 week in air at $20^{\circ} \mathrm{C}$. Firmness was 


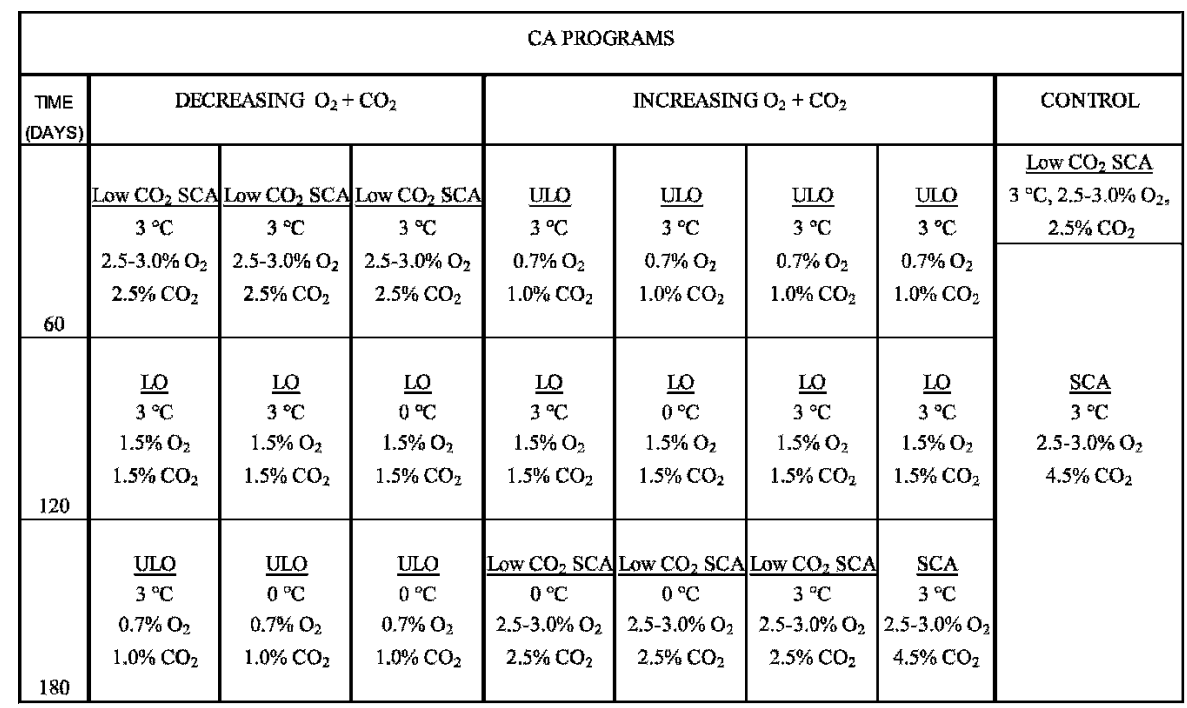

Fig. 1. CA storage programs of 'McIntosh' apples in 2000-2001 after transportation and $12 \mathrm{~h}$ of precooling at $0{ }^{\circ} \mathrm{C}$.

measured on pared opposite sides of 10 fruit from each replicate using a handheld Effegi penetrometer (Alfosine, Italy) fitted with an 11-mm tip.

\section{Physiological disorders assessment}

The incidence of physiological disorders was assessed on day 7 of the 1-week ripening period in air at $20{ }^{\circ} \mathrm{C}$. Ten fruit from each of two replicates were used in year 1 , and 25 fruit from each of three replicates were used in year 2. The incidence of disorders was recorded, including low $\mathrm{O}_{2}$ injury, $\mathrm{CO}_{2}$ injury, core browning, and superficial scald.

\section{Statistical analyses}

As a result of the complexity of the CA regimens, the experimental design was treated as a completely randomized design and each experimental CA was analyzed as a full treatment or program. Analysis of variance (ANOVA) was performed using the GLM procedure of SAS version 8.2 according to (Bowley 1999). To make sure that the ANOVA assumptions were met, an arsine, logarithmic, and square root transformation was performed on the disorder data to determine the best normality of residuals. The normality was checked using the univariate procedure of SAS.

\section{Results and Discussion}

\section{Firmness retention}

During the first year, apples that had been stored in atmospheres of sequential decreasing levels of $\mathrm{O}_{2}$ and $\mathrm{CO}_{2}$ were significantly firmer than fruit from any other treatment after $180 \mathrm{~d}$ of storage (Table 1). However, this firmness difference was not maintained

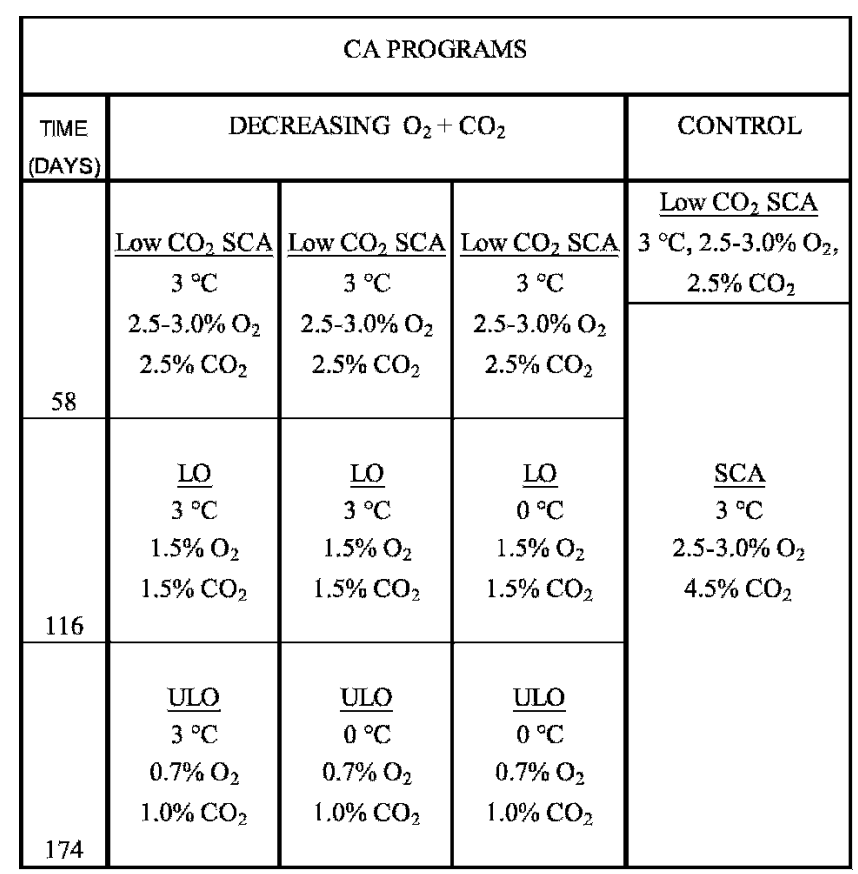

Fig. 2. Postharvest management of 'McIntosh' apples in 2001-2002 after transportation and $12 \mathrm{~h}$ of precooling at $0{ }^{\circ} \mathrm{C}$. over the 1-week ripening period in fruit that was held at a constant temperature of $3{ }^{\circ} \mathrm{C}$. These results conflict with those of Lidster et al. (1987), who found that fruit from CA programs with increasing $\mathrm{O}_{2}$ and $\mathrm{CO}_{2}$ concentrations had better firmness retention after storage than apples that had been held in CA programs decreasing in $\mathrm{O}_{2}$ and $\mathrm{CO}_{2}$ concentrations.

Lowering the temperature after $60 \mathrm{~d}$ during LO regimes increased firmness retention significantly during storage when compared with the fruit stored in SCA continuously. Lowering temperature also reduced softening when compared with the respective sequential treatment stored constantly at $3{ }^{\circ} \mathrm{C}$. No significant difference was observed when the temperature was lowered at 60 or $120 \mathrm{~d}$ during storage.

The pattern of results was similar in the second year of the study. Fruit subjected to a sequential decrease in $\mathrm{O}_{2}$ and $\mathrm{CO}_{2}$ levels were 14.7 to $19.6 \mathrm{~N}$ firmer $1 \mathrm{~d}$ after storage than fruit stored in SCA continuously (Table 2). Decreasing temperature during the sequential decrease in $\mathrm{O}_{2}$ and $\mathrm{CO}_{2}$ also increased firmness retention during the 1 -week ripening period compared with the equivalent treatment stored continuously at $3{ }^{\circ} \mathrm{C}$. This was expected, because storage of 'McIntosh' at $0{ }^{\circ} \mathrm{C}$ has been shown to improve firmness retention when compared with storage at $3{ }^{\circ} \mathrm{C}$ (Lidster et al., 1987). No significant difference in firmness was observed between continuous ULO and the sequential treatment lowered to $0{ }^{\circ} \mathrm{C}$ after two thirds of the total storage time.

\section{Physiological disorders}

Low $\mathrm{O}_{2}$ injury, expressed almost exclusively as purpling of the skin, was observed in some low $\mathrm{O}_{2}$ treatments in year 1 . Fruit stored in sequential ULO, LO, and SCA appeared to develop more low $\mathrm{O}_{2}$ injury than those in any other treatment ( $16 \%$ vs. $0-4 \%$, respectively) and fruit exposed to a SCA regime with $4.5 \%$ $\mathrm{CO}_{2}$ showed the greatest incidence. However, the CA program had no significant effect on the incidence of low $\mathrm{O}_{2}$ injury. It is most likely that the exposure of nonacclimatized fruit to the rapidly established ULO atmospheres was responsible for the high incidence of low $\mathrm{O}_{2}$ injury in fruit stored in atmospheres sequentially increasing in $\mathrm{O}_{2}$ and $\mathrm{CO}_{2}$. Furthermore, fruit exposed to low $\mathrm{O}_{2}$ concentrations is known to be more sensitive to elevated levels of $\mathrm{CO}_{2}$, which can increase the incidence of low $\mathrm{O}_{2}$ injury (Lidster et al., 1990) by augmenting ethanol production (Kader, 1986). During the second year of this study, only fruit stored in constant ULO exhibited skin purpling (25\% incidence) and the CA program was significant at $P \leq 0.0001$. Fruit stored in sequential SCA, $\mathrm{LO}$, and ULO did not develop low $\mathrm{O}_{2}$ injury.

External $\mathrm{CO}_{2}$ injury was observed in year 1 in programs that included a time period with $4.5 \% \mathrm{CO}_{2}$. Fruit stored in continuous SCA and in programs sequentially increasing in $\mathrm{O}_{2}$ and $\mathrm{CO}_{2}$ developed $32 \%$ and $20 \% \mathrm{CO}_{2}$ injury, respectively. Core browning also 
Table 1. Firmness (N) of 'McIntosh' apples during a 1-week ripening period at $20^{\circ} \mathrm{C}$ after $180 \mathrm{~d}$ of storage under different CA conditions in 2000-2001. ${ }^{\mathrm{z}}$

\begin{tabular}{|c|c|c|}
\hline \multirow[b]{2}{*}{ CA programs ${ }^{y}$} & \multicolumn{2}{|c|}{ Days after storage } \\
\hline & 1 & 7 \\
\hline Standard CA & $5505 \mathrm{~b}$ & $49.4 \mathrm{~b}$ \\
\hline \multicolumn{3}{|l|}{ Sequential increase in $\mathrm{O}_{2}$} \\
\hline ULO, LO, and SCA at $3{ }^{\circ} \mathrm{C}$ & $54.4 \mathrm{bc}$ & $41.4 \mathrm{~d}$ \\
\hline $\mathrm{ULO}, \mathrm{LO}$, and low $\mathrm{CO}_{2} \mathrm{SCA}$ at $3{ }^{\circ} \mathrm{C}$ & $52.2 \mathrm{c}$ & $45.7 \mathrm{~cd}$ \\
\hline ULO, LO at $3{ }^{\circ} \mathrm{C}+$ low $\mathrm{CO}_{2} \mathrm{SCA}$ at $0{ }^{\circ} \mathrm{C}$ & $52.5 \mathrm{~b}$ & $45.2 \mathrm{~cd}$ \\
\hline ULO at $3{ }^{\circ} \mathrm{C}+\mathrm{LO}$ and low $\mathrm{CO}_{2}$ SCA at $0{ }^{\circ} \mathrm{C}$ & $56.0 \mathrm{~b}$ & $43.0 \mathrm{~cd}$ \\
\hline \multicolumn{3}{|l|}{ Sequential decrease in $\mathrm{O}_{2}$} \\
\hline Low $\mathrm{CO}_{2} \mathrm{SCA}, \mathrm{LO}$, and $\mathrm{ULO}$ at $3^{\circ} \mathrm{C}$ & $63.8 \mathrm{a}$ & $46.8 \mathrm{bc}$ \\
\hline Low $\mathrm{Co}_{2} \mathrm{SCA}$ and $\mathrm{LO}$ at $3{ }^{\circ} \mathrm{C}+\mathrm{ULO}$ at $0{ }^{\circ} \mathrm{C}$ & $62.4 \mathrm{a}$ & $55.5 \mathrm{a}$ \\
\hline Low $\mathrm{Co}_{2} \mathrm{SCA}$ at $3{ }^{\circ} \mathrm{C}+\mathrm{LO} \& \mathrm{ULO}$ at $0{ }^{\circ} \mathrm{C}$ & $62.1 \mathrm{a}$ & $51.4 \mathrm{a}$ \\
\hline \multicolumn{3}{|l|}{ Significance } \\
\hline CA programs & $* * *$ & $* * *$ \\
\hline Contrast 'sequential increase vs sequential decrease' & $* * *$ & $* * *$ \\
\hline
\end{tabular}

${ }^{\mathrm{z}}$ Firmness at harvest was $67.6 \pm 4.5 \mathrm{~N}$.

${ }^{\text {y }} \mathrm{SCA}=2.5 \%$ to $3.0 \% \mathrm{O}_{2}+2.5 \% \mathrm{CO}_{2}$ for $30 \mathrm{~d}$ followed by $2.5 \%$ to $3.0 \% \mathrm{O}_{2}+4.5 \% \mathrm{CO}_{2}$ for the remaining $150 \mathrm{~d}$ low $\mathrm{CO}_{2} \mathrm{SCA}=2.5 \%$ to $3.0 \% \mathrm{O}_{2}+2.5 \% \mathrm{CO}_{2}$ for $60 \mathrm{~d} ; \mathrm{LO}=1.5 \% \mathrm{O}_{2}+1.5 \% \mathrm{CO}_{2}$ for $60 \mathrm{~d}$; $\mathrm{ULO}=$ $0.7 \% \mathrm{O}_{2}+1.0 \% \mathrm{CO}_{2}$ for $60 \mathrm{~d}$.

$* * *$ Significant at $P \leq 0.001$. Means within the same day with the same letter are not significantly different according to Duncan's multiple range test.

Table 2. Firmness (N) of 'McIntosh' apples during a 1-week ripening period at $20^{\circ} \mathrm{C}$ after $174 \mathrm{~d}$ of storage under different CA programs in 2001-2002. ${ }^{2}$

\begin{tabular}{lcc}
\hline & \multicolumn{2}{c}{ Days after storage } \\
\cline { 2 - 3 } CA programs $^{\mathrm{y}}$ & 1 & 7 \\
\hline Continuous & & $51.5 \mathrm{~d}$ \\
$\quad \mathrm{SCA}$ & $69.5 \mathrm{~b}$ & $58.6 \mathrm{c}$ \\
$\quad \mathrm{ULO}$ & & \\
Sequential decrease in $\mathrm{O}_{2}$ & $71.4 \mathrm{a}$ & $55.3 \mathrm{~b}$ \\
$\quad$ Low $\mathrm{CO}_{2} \mathrm{SCA}, \mathrm{LO}$, and $\mathrm{ULO}$ at $3{ }^{\circ} \mathrm{C}$ & $69.1 \mathrm{~b}$ & $57.8 \mathrm{a}$ \\
$\quad$ Low $\mathrm{CO}_{2} \mathrm{SCA}$ and $\mathrm{LO}$ at $3{ }^{\circ} \mathrm{C}+\mathrm{ULO}$ at $0{ }^{\circ} \mathrm{C}$ & $66.2 \mathrm{c}$ & $58.4 \mathrm{a}$ \\
$\quad$ Low $\mathrm{CO}_{2} \mathrm{SCA}$ at $3{ }^{\circ} \mathrm{C}+\mathrm{LO}$ and $\mathrm{ULO}$ at $0{ }^{\circ} \mathrm{C}$ & $* * *$ & $* * *$ \\
Significance & &
\end{tabular}

${ }^{2}$ Firmness at harvest was $77.4 \pm 2.0 \mathrm{~N}$.

${ }^{\mathrm{y}} \mathrm{SCA}=2.5 \%$ to $3.0 \% \mathrm{O}_{2}+2.5 \% \mathrm{CO}_{2}$ for $30 \mathrm{~d}$ followed by $2.5 \%$ to $3.0 \% \mathrm{O}_{2}+4.5 \% \mathrm{CO}_{2}$ for the remaining $144 \mathrm{~d}$; low $\mathrm{CO}_{2} \mathrm{SCA}=2.5 \%$ to $3.0 \% \mathrm{O}_{2}+2.5 \% \mathrm{CO}_{2}$ for $58 \mathrm{~d}$; $\mathrm{LO}=1.5 \% \mathrm{O}_{2}+1.5 \% \mathrm{CO}_{2}$ for $58 \mathrm{~d}$; $\mathrm{ULO}=$ $0.7 \% \mathrm{O}_{2}+1.0 \% \mathrm{CO}_{2}$ for $58 \mathrm{~d}$.

***Significant at $P \leq 0.001$. Means within the same day with the same letter are not significantly different according to Duncan's multiple range test.

developed in year 1 in apples from all CA programs (10-40\% incidence), except those sequentially decreasing in $\mathrm{O}_{2}$ and $\mathrm{CO}_{2}(0 \%$ incidence). The CA program had no significant effect on the incidence of $\mathrm{CO}_{2}$ injury or core browning, and neither disorder was observed in the second year of this study.

Little superficial scald developed on 'McIntosh' apples during the two storage seasons (average 2\%). There was no statistical significant difference in scald incidence among the different CA programs $(P \leq 0.72$ and $P \leq 0.08$, for year 1 and year 2 , respectively).

\section{Conclusion}

An atmosphere decreasing in $\mathrm{O}_{2}$ from $2.5 \%$ to $3.0 \%$ to $0.7 \%$ and in $\mathrm{CO}_{2}$ from $2.5 \%$ to $1.0 \%$ during long-term storage was effective in retaining firmness of 'McIntosh' apples. In addition, sequential SCA, LO, and ULO regimes were effective at reducing the
E.C. Lougheed. 1987. An international cooperative survey study of McIntosh apple response to low oxygen and standard controlled atmosphere storage. Fruit Sci. Rpt. 14:155-162.

Bowley, S.R. 1999. A hitchhiker's guide to statistics in plant biology.. Any Old Subject Books, a Division of Plants et al., Inc., Guelph, Ontario.

Chen, P.M., K.L. Olsen, and M. Meheriuk. 1985. Effect of low-oxygen atmosphere on storage scald and quality preservation of 'Delicious' apples. J. Amer. Soc. Hort. Sci. 110:16-20.

DeEll, J. and D. Murr. 2003. CA storage guidelines and recommendations for apples. Factsheet No. 03-073. Ontario Ministry of Agriculture and Food.

Kader, A.A. 1992. Effects of controlled atmospheres. Pp. 85-92. In: Khader, A.A. (ed.), Postharvest Technology of Horticultural Crops. University of California Division of Agriculture Sciences Special Publication 3311.

Kader, A.A. 1986. Biochemical and physiological basis for effects of controlled and modified atmospheres on fruit and vegetables. Food Technol. 40:99-104.

Lau, O.L. 1983. Effect of storage procedures and low oxygen and carbon dioxide atmospheres on storage quality of 'Spartan' apples. J. Amer. Soc. Hort. Sci. 108:953-957.

Lau, O.L. 1985. Storage procedures, low oxygen, and low carbon dioxide atmospheres on storage quality of 'Golden Delicious' and 'Delicious' apples. J. Amer. Soc. Hort. Sci. 110:541-547.

Lau, O.L. 1990. Tolerance of three apple cultivars to ultra-low levels of oxygen. HortScience 25:1412-1414.

Lau, O.L., R. Yastremski, and M. Meheriuk. 1987. Influence of maturity, storage procedure, temperature, and oxygen concentration on quality and disorders of 'McIntosh' apples. J. Amer. Soc. Hort. Sci. 112:93-99.

Lidster, P.D., G.D. Blanpied, and R.K. Prange. 1990. Controlled-atmosphere disorders of commercial fruit and vegetables. Agriculture Canada, Pub. 1847/E.

Lidster, P.D., E.C. Lougheed, and K. McRae. 1987. Effects of sequential low-oxygen and standard controlled atmosphere storage regimens on apple quality. J. Amer. Soc. Hort. Sci. 112:787-793.

incidence of low $\mathrm{O}_{2}$ injury, which can develop in continuous ULO. A decline in temperature during the sequential atmosphere regimens provided further benefit by reducing fruit softening during the poststorage ripening period in ambient air compared with storage at a constant temperature. Sequential SCA, LO, and ULO storage, combined with a stepdown in temperature, was the best postharvest treatment in this study. Such storage techniques could be easily integrated within current CA facilities and practices to improve the quality of 'McIntosh' apples during long-term storage.

\section{Literature Cited}

Autio, W.R., W.J. Bramlage, and W.J. Lord. 1990. Ripening and storability of 'Marshall McIntosh' apples. Fruit Var. 44:36-40.

Blanpied, G.D., W.J. Bramlage, D.R. Dilley, D.S. Johnson, E. Lange, O.L. Lau, P.D. Lidster, and
Lidster, P.D. and K.B. McRae. 1985. Retention of apple quality in low-oxygen storage followed by standard controlled-atmosphere regimens. J. Amer. Soc. Hort. Sci. 110:755-759.

Little, C.R. and I.D. Peggie. 1987. Storage injury of pome fruit caused by stress levels of oxygen, carbon dioxide, temperature, and ethylene. HortScience 22:783-790.

Marmo, C.A., W.J. Bramlage, and S.A. Weiss. 1985. Effect of fruit maturity, size, and mineral concentrations on predicting the storage life of 'McIntosh' apples. J. Amer. Soc. Hort. Sci. 110:499-502.

Nichols, W.C. and M.E. Patterson. 1987. Ethanol accumulation and post storage quality of 'Delicious' apples during short-term, low- $\mathrm{O}_{2}$, CA storage. HortScience 22:89-92.

Truter, A.B. and J.C. Combrink. 1994. Control of superficial scald on 'Topred' apples without diphenylamine. Deciduous Fruit Grower 44:168-171.

Wang, Z. and D.R. Dilley. 1999. Control of superficial scald of apples by low-oxygen atmospheres. HortScience 34:1145-1149. 